Aquaculture Research

January 2017, Volume 48, Issue 1, Pages 270-282

http://dx.doi.org/10.1111/are. 12880

Achimer

http://archimer.ifremer.fr/doc/00276/38687/

(c) 2015 John Wiley \& Sons Ltd

\title{
Macro-geographical differences influenced by family-based expression on cultured pearl grade, shape and colour in the black-lip "pearl oyster" Pinctada margaritifera: a preliminary bi-local case study in French Polynesia
}

\author{
Ky Chin-Long ${ }^{1,{ }^{*}}$, Blay Carole ${ }^{1}$, Aiho Vaite ${ }^{2}$, Cabral Philippe ${ }^{3}$, Le Moullac Gilles ${ }^{1}$, Lo Cedrik ${ }^{4}$
}

${ }^{1}$ Ifremer, UMR EIO241, Labex Corail, Centre du Pacifique, BP 7004, 98719 Taravao, Tahiti - Polynésie

Française

${ }^{2}$ Love Here Pearl Farm, Tahaa - Archipel de la Société, Polynésie Française

${ }^{3}$ Gauguin's Pearl Farm, BP 191, Avatoru, Rangiroa - Archipel des Tuamotu, Polynésie Française

${ }^{4}$ Direction des Ressources Marines et Minières, BP 20, 98713 Papeete, Tahiti - Polynésie Française

*Corresponding author : Chin-Long Ky, email address : chinky@ifremer.fr

\begin{abstract}
:
In French Polynesia, the aquaculture of $P$. margaritifera is carried out in numerous grow-out sites, located over three archipelagos (Gambier, Society and Tuamotu). To evaluate the impact of macrogeographical effects of these growing sites on pearl quality traits, five hatcheries produced families were used as homogeneous donor oysters in an experimental graft. The molluscs were then reared in two commercial locations: Tahaa island (Society) and Rangiroa atoll (Tuamotu). At harvest, eight pearl quality traits were recorded and compared: surface defects, lustre, grade, circles, shape categories, darkness level, body and secondary colour and visual colour categories. Overall inter-site comparison revealed that: 1) all traits were affected by grow-out location except for lustre and round shape, and 2) a higher mean rate of valuable pearls was produced in Rangiroa. Indeed, for pearl grade, Rangiroa showed twice as many A-B and less reject samples than Tahaa. This was related to the number of surface defects (grade component): in Rangiroa, twice as many pearls had no defects and less pearls had up to 10 defects. Concerning pearl shape, more circled and baroque pearls were found in Tahaa $(+10 \%)$. For colour variation, $10 \%$ more pearls have an attractive green overtone in Rangiroa than in Tahaa, where more grey bodycolor were harvested. Lustre does not seem to be affected by these two culture site (except at a family scale). This is the first time $P$. margaritifera donor family have been shown to vary in the quality of pearls they produce depending on their grow-out location.
\end{abstract}

Keywords : Pinctada margaritifera, cultured pearl quality, grow-out location, environment 


\section{Introduction}

Tahitian "Black" South Sea cultured pearl production is based on aquaculture of Pinctada margaritifera a mollusc commonly known as the black-lip "pearl oyster". French Polynesia presently dominates black cultured pearl production, with 487 pearl farms, covering near 7800 ha of maritime surface area over 25 atolls or islands distributed among three archipelagos: Gambier, Society and Tuamotu (DRMM 2013 statistics). Other countries of the Pacific region, such as the Cook Islands, Fiji islands or Micronesia, have also developed pearl farming industries based on $P$. margaritifera (Cartier et al. 2013). The production of a cultured pearl is a two-step process involving an initial two year oyster grow-out phase and then requiring a further two years after grafting to grow the actual pearl. The grafting process is essentially a surgical operation conducted by a trained technician, who inserts a small piece of tissue (saibo) cut from the outer mantle edge of a sacrificed "donor oyster", along with a small bead nucleus as for the most of saltwater pearls cultivation, into the gonad of a second "recipient oyster". Thus, the pearl culture process involves two oysters, each of which may genetically contribute directly or indirectly to one or more pearl quality traits, in interaction with the environment.

Tahitian cultured black pearl quality is determined according to a wide range of criteria, including pearl classification grade, surface quality and lustre, shape, colour (bodycolor and overtone), darkness level and size (Tayale et al., 2012; Ky et al., 2013; Ky et al., 2015a). Tahitian classification grading (Journal Officiel $2001 n^{\circ} 30,26$ July 2001) is an evaluation made with the naked eye (i.e., without any magnification device such as a jeweller's loupe), to grade pearls into five classes: A, B, C, D and R (rejects), the last of which are below class $\mathrm{D}$ quality and cannot be exported from Tahiti. This classification grading is determined by two components: pearl surface quality and lustre. Shape is also one of the principle determining factors of a cultured pearl's value; with the rounder the pearl, the more valuable it is (Ky et al., 2014b). Circled pearls generally account for $25-30 \%$ of a Tahitian cultured pearl harvest. Another remarkable specificity of the $P$. margaritifera pearl oyster is its ability to produce a wide range of pearl colours (Ky et al., 2013). Cultured pearl colour is defined according to two main characteristics: 1) the bodycolor, which is the dominant, overall colour of a pearl determined by a combination of several pigments; 2) the secondary colour, which display one or more additional overtones of colour in the reflection, but also diffusion and/or diffraction from the top layers of the nacre surface (Karampelas et al., 2011). The predominant bodycolors are white, yellow, black and grey and the secondary colours are green, aubergine (red/ purple) and peacock (a mix of aubergine and green) (Tayale et al., 2012; Ky et al., 2013; Ky et al., 2014b). Cultured pearl size (ranging from 8.0 to $20 \mathrm{~mm}$ ) determines value, with larger pearls generally commanding higher prices (Blay et al., 2014). The factors that contribute to cultured pearl quality include the oyster species and the environmental quality of the culture zone where the recipient oyster is reared during pearl development (Gervis and Sims, 1992; Southgate and Lucas, 2008).

Understanding the influence of environment in the realisation of cultured pearl is particularly important, as numerous farms and grow-out sites are geographically distant and subject to disparate environmental regimes in French Polynesia. For example, in the context of a breeding program for pearl quality traits an understanding of the interactions between animals and environment is essential to ensure maximum genetic gains when multiple growout locations are used or targeted for the end product (Wada and Jerry, 2008). To date, there have been few studies on family-specific interaction with environment in pearl oysters and all concern the silver-lip pearl oyster, $P$. maxima. Two of them have been restricted to survival and shell growth traits in (Kvingedal et al., 2008; 2010). Kvingedal et al. (2008) showed that families of 43-day-old $P$. maxima spat, when reared under different nursery culture conditions, exhibited environment-dependent growth patterns. Another study where potential environment impacts were examined in $P$. maxima, this time for pearl quality traits, was conducted in Indonesia by Jerry et al. (2012) who reported significant interactions on 
cultured pearl size, colour, weight, shape and lustre due to differential ranking of families based on the relative performances at two commercial grow-out locations (Bali and Lombok). To date, no studies have treated the effects that environment could have on cultured pearl quality traits in $P$. margaritifera.

The aim of our study was therefore to evaluate the possible influence of macro-geographical grow-out sites on cultured pearl quality traits in $P$. margaritifera, namely: grade, surface defects, lustre, shape, circles, colour and its components (darkness level, body and secondary colours). This preliminary study will help for future breeding programs, that are likely to involve the rearing of oysters in geographically disparate locations. The present study was based on an experimental graft method where the grafting process was kept as uniform as possible by using same expert grafter, nucleus size, graft site and method (as for commercial grafting), donor oyster families (hatchery-produced) and recipient oyster source. To isolate environmental effects, grow-out was then conducted in two contrasting locations: Tahaa island lagoon (Society archipelago) and Rangiroa atoll lagoon (Tuamotu archipelago) (Figure 1).

\section{Materials and methods}

\subsection{Experimental animals}

Five bi-parental families of pearl oysters, named F058, F612, F804, F805 and F806, were produced in a hatchery system at the Ifremer facilities in Vairao, Tahiti, French Polynesia. Spawning was induced by thermal shock following the procedures described in Ky et al. (2013). Breeding was conducted using five males and five females from the wild (unselected for growth performance or particular inner shell colour phenotype) broodstock pearl oysters from Takapoto atoll (Tuamotu Archipelago, French Polynesia). To avoid cross breeding contamination, the methods described in Ky et al (2013 and 2014b) were used. Cleaning of female gametes, sperm motility checking and fertilization ratio were also described in the previously cited studies. After 24 hours, the D-shaped larvae were collected on $45-\mu \mathrm{m}$ screens and each family was reared separately in a through flow culture system (Hui et al, 2011). Individuals of the five families, which were to be used as donor oysters, were grown at the field for 20 months and then transferred by plane to Rangiroa atoll (Tuamotu Archipelago), 2 months prior to nucleus implantation to allow the oysters to adapt to local environmental conditions.

\subsection{Experimental grafting design}

As the grafting operation may influence cultured pearl quality, all grafts were undertaken by a single professional technician. A total of 50 donors (10 per family) were used to perform 1500 grafts (30 grafts per donor) over a 3 day period in Gauguin's Pearl farm (Rangiroa atoll - Tuamotu archipelago) under the same conditions as for a commercial graft (Figure 1). Each recipient pearl oyster came from natural spat collection from the wild. They were selected based on visible health status (colour of the visceral mass and gills), shell size appearance, and muscle resistance when the shells were pried open. Each recipient was grafted using a 2.4 BU nucleus (7.304 mm diameter - Nucleus Bio, Hyakusyo Co. Japan). At 45 days post graft operation recipient oysters were checked to estimate nucleus retention, nucleus rejection and oyster mortality rates were done as described in Ky et al. (2014a). After this check, recipient oysters that had retained their nuclei (no bead detected in the bags) were drilled and randomly fixed to chaplets (in the chaplets, oysters were attached in pairs to a rope with a monofilament fishing line) in two groups, after removing the net retention bags. As each chaplet was labelled according to the corresponding donor oyster (for traceability between donor and recipient), each donor oyster was represented by 2 chaplets. The 100 
chaplets (each corresponding to one donor oyster) were split into two groups to be reared in two culture sites (50 chaplets per site), where each donor was equally represented per site. One of the two groups (607 oysters) was transferred by plane to Tahaa island $\left(16^{\circ} 37^{\prime} \mathrm{S}\right.$, $151^{\circ} 30^{\prime} \mathrm{W}$ ), whereas the other (574 oysters) was maintained in Rangiroa atoll $\left(15^{\circ} 07^{\prime} \mathrm{S}\right.$, $147^{\circ} 38^{\prime} \mathrm{W}$ ) to evaluate site-specific environment influences on cultured pearl quality traits (Figure $1 \& 2$ ). The "oysters" on chaplets were put in cooled iceboxes (without water) and the overall transfer operations took 4 hours from water to water. Furthermore, pearl oysters were regularly cleaned in both sites, during the same periods and at the same frequency in order to remove biofouling (epibiota), which can hinder healthy oyster growth and pearl production.

\subsection{Measurement of cultured pearl quality traits}

After 16 months of culture in both Rangiroa and Tahaa sites, the cultured pearls were harvested and placed into a compartmented box that allowed traceability between sample pearls and corresponding donor oysters. Some keshi (small irregular shaped nacreous but non-nucleated pearls that form during the culture time after nuclei have been rejected) could also be harvested, but not graded. Cultured pearls were then cleaned by ultrasonication in soapy water (hand washing) with a LEO 801 laboratory cleaner (2L capacity, $80 \mathrm{~W}, 46 \mathrm{kHz}$ ) according to Ky et al. (2013).

Cultured pearl quality traits: surface defects, lustre, grade, circle, shape, darkness level, and colour categories were evaluated visually (without loupe) by two operators working in cooperation, as described in Ky et al. (2013 and 2014b).

\section{4. Environmental factors}

For this inter-site comparison, made at the macro-geographic scale, the main environmental parameters (i.e., water temperature, nutrient levels), including seasonal variability, were deliberately not reported. Indeed, one goal of this study was to evaluate the impact that culture locations in French Polynesia had on cultured pearl quality traits realization over a wide geographic area. Both the environmental knowledge about the contrasting grow-out locations and the impact that food availability and temperature have on growth contribute to explaining the overall geographical variability observed in the present study. Indeed, these two main environmental parameters have been shown to influence growth and the biomineralization process in bivalves (Laing, 2000; Pouvreau and Prasil, 2000; Schöne et al., 2005).

\section{5. Statistical analysis}

Differences in nucleus retention and rejection rate, oyster mortalities and harvested pearl and keshi rate in the five families in each grow-out location were evaluated using $x^{2}$ tests.

Qualitative categories based on cultured pearl surface defects, lustre, grade, presence or absence of circles and darkness were re-encoded to give quantitative scores that would enable the mean value of families to be obtained for each trait, thus allowing them to be ranked. Scores from 0 to 4 were attributed to the different classes from the least to the most valuable (based on surface defects, lustre, grade circles and darkness) according to Ky et al. (2013 and 2014b). Due to non-normality of the variable distributions, non-parametric Kruskall-Wallis tests were used to test for differences between families in each grow out site.

For cultured pearl shape categories, presence / absence of secondary colour and visual colour categories, difference between families and effect of family in an intra-site level were evaluated using $\mathrm{x}^{2}$ tests. 
Inter-culture site effect was evaluated for each quality trait category at two levels, by considering: 1) the cumulated value of the five families using $x^{2}$ test, and 2) each family separately using Fisher's exact test (differences represented by asterisks in figure histograms).

In all tests, p-values lower than 0.05 were considered significant (Dagnelie 2007). All analyses were performed using XLSTAT (version 2009.4.02) and R software (version 2.14.1).

\section{Results}

\subsection{Nucleus retention and cultured pearl harvest}

The 1500 grafted pearl oysters showed an average rate of $78.6 \%$ nucleus retention $(\mathrm{N}=$ $1181), 15.2 \%(\mathrm{~N}=228)$ nucleus rejection and $6.1 \%(\mathrm{~N}=91)$ of mortality and/or predation (Table 1). No donor family effect was detected for nuclei retention $(p=0.598)$. In contrast, both nucleus rejection and mortality / predation showed significant donor family effects at 45 days post grafting: $p=0.022$ (Table 1 ).

A total of 956 cultured pearls were harvested: 468 pearls in Rangiroa atoll and 488 pearls in Tahaa island (Table 2). No significant donor family effect or site effect was detected for the rate of harvested pearls $(p=0.414$ and $p=0.363$, respectively). The rate of harvested keshi showed a highly significant site effect $(p=0.004)$. Significant donor family effect for harvested keshi was detected at both culture sites $(p=0.044$ for Rangiroa and $p=0.011$ for Tahaa). No family effect was detected for mortality / predation rate in either culture site, although a highly significant site effect was detected $(p=0.006)$.

\subsection{Cultured pearl surface defects and lustre as components of grade}

For the cultured pearl surface defects, table 3 showed the distribution in both site. Inter culture site comparison revealed a very highly significant site effect $(p=0.002)$ for the two categories: 1) without any defects, and 2) with more than 10 defects (Table 3 ). Among the families, three showed a significant site effect: F058, F612 and F804. Family F058 showed a significantly $(p=0.009)$ higher proportion of pearls with no defects in Rangiroa, than in Tahaa, with nearly a 4-fold difference (Figure 2a). This family also produced a significantly greater percentage of pearls with 6 to 10 defects in Tahaa than in Rangiroa, with two-fold difference $(p=0.016)$. Family F612 showed the same tendency as family F058, with: 1) $20.0 \%$ of pearls without any defects in Rangiroa, compared with $2.8 \%$ in Tahaa $(p=0.0002)$, and 2) nearly twice as many cultured pearls with 6 to 10 defects in Tahaa as in Rangiroa ( $p=$ 0.021 ) (Figure 2a). Pearls from family F804 showed a significant site effect for: 1) 1 to 5 defects class $(p=0.025)$, with more in Rangiroa $(+37.5 \%)$, and 2$)>10$ defects class $(p=$ 0.018 ), with more in Tahaa (2.5 times more) (Figure $2 \mathrm{a}$ ). Concerning the donor family effect, a very highly significant effect was detected in Rangiroa $(p=0.003)$, whereas no significant effect was observed in Tahaa $(p=0.339)$.

For cultured pearl lustre, no significant site effect was detected at the inter-site comparison level $(p=0.289)$ (Table 3). Between the five families, F804 was the only one that showed a significant site effect for lustre $(p=0.017)$, with $10 \%$ more shiny pearls in Rangiroa than in Tahaa (Figure $2 b$ ). Concerning the donor family effect, a significant effect was detected in Rangiroa $(p=0.039)$, whereas no significant effect was observed in Tahaa $(p=0.107)$.

For the cultured pearl grade, table 3 showed the distribution in both site. Inter culture site comparison revealed a very highly significant site effect on cultured pearl grade with $p<$ 0.0001 for all categories except grade $\mathrm{C}$, when average of all the families was considered 
(Table 3). Inter culture site differences were shown in each of the families except for F805 (Figure 2c). Pearls from family F058 showed a significant site effect for grade B $(p=0.004)$, with more in Rangiroa (+19\%). F612 showed significant site effects for 3 grade categories: 1) grade A, with nearly 20 -fold more in Rangiroa than in Tahaa $(p<0.0001) ; 2)$ grade B with nearly 3-fold more in Rangiroa than in Tahaa $(p=0.004)$; and 3), grade $D$ with, inversely, nearly 2 -fold more in Tahaa than in Rangiroa ( $p=0.004$ ) (Figure $2 \mathrm{c}$ ). Family F804 showed a significantly $(p=0.009)$ higher rate of grade R pearls in Tahaa than in Rangiroa (nearly 2 fold) (Figure 2c). By contrast, family F806 had a significantly $(p=0.04)$ higher rate of grade A pearls in Rangiroa than in Tahaa (nearly 2 fold) (Figure 2c). Data analysis showed a significant family effect on cultured pearl grade in Tahaa $(p=0.05)$, but none in Rangiroa ( $p$ $=0.078$ ).

\subsection{Circled cultured pearl and shape}

Inter culture site comparison revealed a very highly significant site effect on cultured pearl circles, with $p=0.003$. Rangiroa atoll showed a higher proportion $(+10 \%)$ of cultured pearls without circles (68\% vs. $59 \%$ ) (Table 3 ). Inter culture site comparison for incidence of circled pearl in each of the families showed a significant site effect in the three families F058 ( $p=$ $0.0004), \mathrm{F} 612(p=0.0005)$ and F804 ( $p=0.016)$. All of these families presented a higher rate of pearls without circles in Rangiroa than in Tahaa; thus F058, F612 and F804 showed $75 \%, 83 \%$ and $70 \%$ without circles in Rangiroa, but in Tahaa they showed $49 \%, 61 \%$ and $53 \%$, respectively. The inter-site difference for this trait in these families therefore represented nearly $20 \%$. A donor family effect was detected for the presence/ absence in Rangiroa $(p<0.0001)$ and in Tahaa $(p=0.037)$.

Table 3 showed the distribution of the harvested pearl according to their shapes in both site. Inter culture site comparison revealed no significant effect for the "R" shape category $(p=$ 0.268 ). By contrast, a very highly significant site effect was recorded for "O" shape ( $p<$ 0.0001 ), with a near two fold more in Rangiroa than in Tahaa (Table 3). In addition, for the "BQ" shape, $10 \%$ more were found in Tahaa. Inter site comparison between each of the families revealed that two of them showed a significant site effect: F612 $(p=0.001)$ and F804 $(p=$ $0.017)$. Family F612 showed a higher proportion of "BQ" cultured pearls in Tahaa $(+15 \%)$ in comparison with Rangiroa ( $p=0.023$ ) and, inversely, a higher proportion of "O" shape in Rangiroa (+9 times) than in Tahaa $(p<0.001)$. Family F804 has the same tendency as family F612 for "BQ" shape, which was more frequent $(p=0.05)$ in Tahaa than in Rangiroa $(+13 \%)$. A higher proportion of "O" shape was also detected $(p=0.013)$ in family F804 in Rangiroa, with $8 \%$ of pearls in the "O" category compared with $1 \%$ in Tahaa. In this last site, a significant family effect was detected $(p=0.05)$ and none in Rangiroa $(p=0.208)$.

\subsection{Cultured pearl colour: darkness level and visual colour categories}

Inter culture site comparison revealed a very highly significant site effect on cultured pearl darkness level $(p=0.002)$. Twice as many dark pearls were produced in the Rangiroa site ( $p$ $=0.001$ ) as in Tahaa. By contrast, the Tahaa site exhibited $6 \%$ more of the palest cultured pearls than in Rangiroa $(p=0.043$ ) (Table 3). Inter culture site comparison in each of the five families, revealed significant family effect for three of them: F058 ( $p=0.002), \operatorname{F612}(p=$ $0.019)$ and F806 ( $p<0.0001)$. Family F058 showed: 1$)$ nearly twice as many pale pearls in Tahaa than in Rangiroa $(p=0.013), 2)$ nearly 5 times more dark pearls in Tahaa than in Rangiroa $(p=0.04)$, and 3) more moderate darkness level pearl in Rangiroa $(+25 \%)$ than in Tahaa $(p=0.001)$. Family F612 and F806 presented higher rates of dark cultured pearls in Rangiroa than in Tahaa with nearly 3 times and 10 times more, respectively (Figure 3a). Concerning the donor family effect, a very highly significant effect was detected in Rangiroa $(p<0.001)$, whereas no significant effect was observed in Tahaa $(p=0.229)$. 
Inter culture site comparison revealed a very highly significant site effect on cultured pearl body and secondary colour $(p=0.0002)$. Rangiroa atoll showed a higher proportion $(+12 \%)$ of cultured pearls with secondary colours than Tahaa (Table 3). Inter culture site comparison for each of the five families showed that three were significantly different between sites: F612 $(p=0.023)$, F804 $(p<0.0001)$ and F806 $(p=0.028)$. All these families showed a higher proportion of pearls with secondary colour in Rangiroa than in Tahaa, with: $+16 \%$ (F612), + $41 \%$ (F804) and $+14 \%$ (F806) (Figure $3 b$ ). In both site, a very highly significant donor family effect was detected for this site.

Table 3 showed the distribution of the harvested pearl according to their colour in both site. Inter culture site comparison revealed a very highly significant site effect on cultured pearl colour $(p<0.0001)$. Rangiroa atoll showed a higher proportion of green and aubergine pearls ( $p=0.001$ and $p<0.0001$, respectively) (Table 3 ). Tahaa site showed a higher proportion of grey and peacock samples $(p<0.001$ and $p=0.003)$. Inter culture site comparison between each of the families showed a significant site effect for all the families $(p<0.001)$ (Figure 3c). Family F058 was only significantly different $(p=0.01)$ for the aubergine colour, which accounted for a far greater proportion in Rangiroa $(5 \times)$ than in Tahaa. Family F612 showed three colour: grey, green and peacock in the Tahaa site. These three colours were also found in the Rangiroa harvest, but with the white colour in addition, which was absent from Tahaa. For this family, the proportion of green pearls was significantly $(p=0.05)$ greater in Rangiroa than in Tahaa $(+13 \%)$. In contrast, there were significantly more grey pearls in Tahaa than in Rangiroa $(p=0.004 ;+20 \%)$. Family F804 showed significantly $(p<0.001): 1)$ more aubergine $(+11 \%)$ and green $(+35 \%)$ pearls in Rangiroa than in Tahaa, and 2$)$ more grey pearls $(+35 \%)$ in Tahaa than in Rangiroa. Family F805 showed a significant site effect for yellow pearls, which were more frequent in Rangiroa $(+8 \%)$ than in Tahaa. In contrast, this family had $8 \%$ peacock pearls in Rangiroa compared with $26 \%$ in Tahaa $(p=0.001)$ (Figure 3c). Donor family F806 produced aubergine colour pearls in Rangiroa, but not in Tahaa. Conversely, no white pearls were harvested from this family in Rangiroa. In both site, a very highly significant donor family effect was detected for this site.

\section{Discussion}

This study was the first to examine whether macro-geographical differences influenced family-based phenotypic expression of cultured pearl quality traits in $P$. margaritifera. Accordingly, in this study we recorded eight cultured pearl quality traits in families of $P$. margaritifera when reared at two grow-out locations and showed that: 1) within each growout site, family effect was detected for grade, shape and visual colour categories, as already reported by Ky et al (2013) working with hatchery produced families; 2) average grow-out site effect (comparison between mean value of the five families for each variable) existed for all variables except for lustre; and 3) family grow-out site effects (comparison between each of the family) also revealed variation in quality traits.

Family-specific pearl quality trait differences were found in our study, indicating the high levels of variability available for selection within populations. For cultured pearl grade (and its components: surface defects and lustre), the pattern of family grade was comparatively different between sites, whereby the most valuable families (from a pearl quality trait perspective) at one location tended not to be the most valuable at the other; for example, family F612 showed the highest rate of grade A pearls in comparison with the other families at the Rangiroa grow-out site, but had the lowest rate in Tahaa. This tendency was also observed for the circle trait. Indeed, family F058 exhibited the highest proportion of cultured pearls without circles compared with the other families at the Rangiroa site, but was the one showing the lowest rate of circles in the Tahaa site. As the experimental graft was uniform (same: grafter, nuclei size and brand, donor oyster families and source of recipient), and animals reared during a same period, circle trait differences observed could not be attributed 
to grafter skill or seasonal variations (Ky et al., 2015). In addition, these differences could also not be attributed to the "oysters" transfer by plane as all the families were not affected in the same way. Therefore, we conclude that environment and interactions with family quality traits are of major consequence as results with the same donor families cultured at the Tahaa and Rangiroa sites differ for such quality traits, as classified by categories on a continuous scale and determined by expert eye of professional pearl graders. Although a previous study showed that inter site differences in shell growth traits, quantitatively measured on a continuous scale in Pinctada maxima (Kvingedal et al., 2010), were of minor consequence between sites in Indonesia as the pattern of family growth performance was comparatively similar and ranking maintained, our present study has revealed environment effects with important ramifications. These effects should be considered in the design of pearl oyster breeding programs to improve quality traits. Nevertheless, our data suggest that the majority of family-determined quality traits, and thus the potential of oysters to produce high quality pearls, would be expressed regardless of which of the two sites the oysters were reared in.

The quality of a harvested cultured pearl is linked to the biomineralisation process, which is still poorly understood. Additionally, after the point of nucleus implantation into a host oyster, the farmer has limited control over how a pearl develops. The effect of site on pearl quality traits has never been previously evaluated in $P$. margaritifera. By contrast, the effect of site on shell growth had been evaluated, with previous studies suggesting that localised site effects significantly influence growth in black-lip pearl oysters. As the mantle, which is responsible for the biomineralisation process, is implicated in both shell growth and nacreous layers deposit on the nucleus, if site effects influence growth, they will probably also impact pearl quality, as confirmed by our results. For example, both Sims (1994) and Pouvreau and Prasil (2000) demonstrated significant site-specific growth effects on $P$. margaritifera reared in the Cook Islands and French Polynesia, and Yukihira et al. (2006) also found that growth rates differed greatly between $P$. margaritifera reared at two dissimilar sites within the Great Barrier Reef lagoon, Australia. Whilst the actual cause of these growth differences among grow-out sites is unknown, field studies show that water temperature, food availability, salinity and current flow rate all have an influence on growth (reviewed in Saucedo et al., 2005). Differences in grow-out site between the lagoons of Tahaa island and Rangiroa atoll were large and complex, involving variations in multiple parameters. One of the most important groups of factors is the variations in physical water parameters during the long period necessary for pearl culture. In fact, the biomineralisation process of a cultured pearl is known to be affected by both temperature and salinity (Kvingedal, 2008). Joubert et al (2014) showed that shell growth is influenced by both microalgal concentration and temperature and also that these environmental factors regulate the expression of most of the gene matrix protein. Olson et al (2012) found a strong correlation between $P$. margaritifera shell nacre ultrastructure with environmental temperature and pressure. The Society archipelago, where Tahaa island is located, is characterised by a significant rainy period (mostly during summer season) in comparison to Tuamotu archipelago, where Rangiroa atoll is located. Thus, seasonal variation in salinity may be more accentuated in Tahaa than in Rangiroa. These rainy periods in Tahaa may also drain some minerals and other nutrients or pollutants from the mountains, which did not occur in the atoll of Rangiroa as there are no mountains there. Such differences would also have an impact on food availability and the nutritional value of the specific and differing microalgae populations that grow in the two contrasting grow-out locations. Given that the sites experience different annual water temperature, different phytoplankton abundance and species, and are exposed to different current velocities, these environmental effects are likely to have contributed to the site-specific differences in cultured pearl quality detected. 


\section{Conclusions}

In this experiment, there were significant differences in cultured pearl quality traits recorded on pearls produced with grafts from five full-sib families reared under the two contrasting grow-out sites. Even though the number of families we evaluated in this experiment was relatively low, the fact that we found differences in family response for cultured pearl quality traits indicated that environment and interaction with family effect on cultured pearl quality expression are important in $P$. margaritifera. In addition, awareness of their potential impact may need to be considered if oysters are going to be reared under disparate environments such in future genetic selection programs.

\section{Acknowledgements}

This work was supported by grants from the Direction des Ressources Marines et Minières (Marché négocié 2013-2014). We would also especially like to thank the two host sites, Love Here Pearl farm (Tahaa island, Society archipelago, French Polynesia) and Gauguin's Pearl Farm (Rangiroa atoll, Tuamotu archipelago, French Polynesia) for their generous assistance.

\section{References}

Blay C., Sham-Koua M., Vonau V., Tetumu R., Cabral P., Ky C.L. (2014) Influence of nacre rate on cultured pearl grade and colour in the black lipped pearl oyster Pinctada margaritifera using farmed donor families. Aquaculture International, 22 (2), 937-953.

Cartier EL, Krzemnicki MS, Ito M (2013) Cultured pearl farming and production in the Federated States of Micronesia. Gems and Gemnology 48: 108-122

Dagnelie P. (2007). Statistique théorique et appliquée, 3rd edn. De Boeck Université, Bruxelles. $734 \mathrm{pp}$.

Gervis M.H., Sims N.A. (1992) The Biology and Culture of Pearl Oysters (Bivalvia Pteriidae), International Centre for Living Aquatic Ressources Management (ICLARM). Stud. Rev. 21, 49.

Hui B., Vonau V., Moriceau J., Tetumu R., Vanaa V., Demoy-Schneider M., Suquet M., Le Moullac G. (2011) Hatchery-scale trials using cryopreserved spermatozoa of black-lip pearl oyster (Pinctada margaritifera). Aquatic Living Resources 24, 219-223.

Jerry D.R., Kvingedal R., Lind C.E., Evans B.S., Taylor J.U., Safari A.E. (2012) Donor oyster derived heritability estimates and the effect of genotype $x$ environment interaction on the production of pearl quality traits in the silver-lip pearl oyster, Pinctada maxima. Aquaculture 338, 66-71.

Joubert C, Linard C, Le Moullac G, Soyez C, Saulnier D, Teaniniuraitemoana V, Ky CL, Gueguen Y (2014) Temperature and Food Influence Shell Growth and Mantle Gene Expression of Shell Matrix Proteins in the Pearl Oyster Pinctada margaritifera. PLoS ONE 9(8): e103944. doi:10.1371/journal.pone.0103944 
Karampelas S., Fritsch E., Gauthier J.-P., Hainschwang T., (2011) UV-Vis-NIR reflectance spectroscopy of natural-color saltwater cultured pearls from Pinctada margaritifera. Gems \& Gemology, 47, 31 - 37.

Kvingedal R., Evans B.S., Taylor J.U., Knauer J., Jerry D.R. (2008) Family by environment interactions in shell size of 43-day old silver-lip pearl oyster (Pinctada maxima), five families reared under different nursery conditions. Aquaculture 279, 23-28.

Kvingedal R., Evans B.S., Lind C.E., Taylor J.J.U., Dupont-Nivet M., Jerry, D.R. (2010)

Population and family growth response to different rearing location, heritability estimates and genotype $\times$ environment interaction in the silver-lip pearl oyster (Pinctada maxima). Aquaculture 304, 1-6.

Ky C.L., Blay C., Sham-Koua M., Vanaa V., Lo C., Cabral P. (2013) Family effect on cultured pearl quality in black-lipped pearl oyster Pinctada margaritifera and insights for genetic improvement. Aquatic Living Resource, 26, 133-145.

Ky C.L., Molinari N., Moe E., Pommier S. (2014a) Impact of season and grafter skill on nucleus retention and pearl oyster mortality rate in Pinctada margaritifera aquaculture. Aquaculture International, 22, 1689-1701.

Ky C.L., Blay C., Sham-Koua M., Lo C., Cabral P. (2014b) Indirect improvement of pearl grade and shape in farmed Pinctada margaritifera by donor oyster selection for green pearls. Aquaculture, 432, 154-162.

Ky C.L., Blay C., Lo C. (2015a) Half-sib families effect on cultured pearl quality traits in the black-lipped pearl oysters Pinctada margaritifera: testing for indirect benefits of polyandry and polygyny. Aquaculture International, in press, DOI 10.1007/s1049-015-9917-4.

Ky CL, Nakasai S, Molinari N, Devaux D (2015b) Influence of grafter skill and season on cultured pearl shape, circles and rejects in Pinctada margaritifera aquaculture in Mangareva lagoon. Aquaculture, 435, 361-370.

Laing I. (2000) Effect of temperature and ration on growth and condition of king scallop Pecten maximus spat. Aquaculture, 183, 325-334.

Olson I.C., Kozdon R., Valley J.W., Gilbert P.U. (2012) Mollusk shell nacre ultrastructure correlates with environmental temperature and pressure. J Am Chem Soc, 134 (17): 7351-8

Pouvreau S., Prasil V. (2000) Growth of the black-lip pearl oyster, Pinctada margaritifera, at nine culture sites of French Polynesia: synthesis of several sampling designs conducted between 1994 and 1999. Aquatic Living Resources 14, 155-163.

Schöne B.R., Houk S.D., Freyre Castro A.D., Fiebig J., Oschmann W., Kröncke I., Dreyer W., Gosselck F. (2005) Daily growth rates in shells of Arctica islandica: assessing sub-seasonal environmental controls on a long-lived bivalves mollusk. Society for Sedimentary Geology, 20, 78-92.

Saucedo P.E., Bervera-Leon H., Monteforte M., Southgate P.C., Monsalvo-Spencer P. (2005) Factors influencing recruitment of hatchery reared pearl oyster (Pinctada mazatlanica; Hanley 1856) spat. Journal of Shellfish Research 24, 215-219.

Sims N.A. (1994) Growth of wild and cultured black-lip pearl oysters, Pinctada margaritifera (L) (Pteriidae, Bivalvia), in the Cook-islands. Aquaculture 122, 181-191. 
Southgate P.C., Lucas J.S. (2008) The Pearl Oyster Elsevier, Oxford (2008) 575 pp.

Tayale A., Gueguen Y., Treguier C, Le Grand J., Cochennec-Laureau N., Montagnani C., Ky C.L. (2012) Evidence of donor effect on cultured pearl quality from a duplicated grafting experiment on Pinctada margaritifera. using wild donors. Aquat. Living Resour. 25, 269-280.

Yukihira H., Lucas J.S., Klumpp D.W. (2006) The pearl oysters, Pinctada maxima and P. margaritifera, respond in different ways to culture in dissimilar environments. Aquaculture $252,208-224$.

Wada K.T., Jerry D.R. (2008) Population genetics and stock improvement. In: Southgate, P.C., Lucas, J. (Eds.), The Pearl Oyster. Elsevier, Oxford, pp. 437-471.

\section{Tables}

Table 1. Summary of grafted $P$. margaritifera "oysters" at 45 days post grafting: number and percentage (in brackets) of oysters by donor family that had retained their nuclei, rejected their nuclei, or died due to natural mortality and/or predation. After this checking operation, the oysters that had retained their nucleus were divided into two groups: one that was kept in Rangiroa and the other that was transferred to Tahaa.

$$
t_{0} \quad t_{45} \text { days post-graft }
$$

\begin{tabular}{|c|c|c|c|c|c|c|}
\hline $\begin{array}{c}\text { Donor } \\
\text { families }\end{array}$ & $\begin{array}{l}\text { Oysters } \\
\text { grafted }\end{array}$ & $\begin{array}{l}\text { Oysters } \\
\text { that } \\
\text { retained } \\
\text { their } \\
\text { nuclei }\end{array}$ & $\begin{array}{l}\text { Oysters } \\
\text { that } \\
\text { rejected } \\
\text { their } \\
\text { nuclei }\end{array}$ & $\begin{array}{l}\text { Mortality } \\
\text { and/or } \\
\text { predation }\end{array}$ & $\begin{array}{c}\text { Kept in } \\
\text { Rangiroa }\end{array}$ & $\begin{array}{c}\text { Transferred } \\
\text { to Tahaa }\end{array}$ \\
\hline F058 & 300 & $\begin{array}{c}228 \\
(76.0)\end{array}$ & $\begin{array}{c}58 \\
(19.3)\end{array}$ & $\begin{array}{c}14 \\
(4.7)\end{array}$ & 111 & 117 \\
\hline F612 & 300 & $\begin{array}{c}243 \\
(81.0)\end{array}$ & $\begin{array}{c}44 \\
(14.7)\end{array}$ & $\begin{array}{c}13 \\
(4.3)\end{array}$ & 117 & 126 \\
\hline F804 & 300 & $\begin{array}{c}233 \\
(77.7)\end{array}$ & $\begin{array}{c}54 \\
(18.0)\end{array}$ & $\begin{array}{c}13 \\
(4.3)\end{array}$ & 114 & 119 \\
\hline F805 & 300 & $\begin{array}{c}240 \\
(80.0)\end{array}$ & $\begin{array}{c}32 \\
(10.7)\end{array}$ & $\begin{array}{c}28 \\
(9.3)\end{array}$ & 117 & $100^{*}$ \\
\hline F806 & 300 & $\begin{array}{c}237 \\
(79.0)\end{array}$ & $\begin{array}{c}40 \\
(13.3)\end{array}$ & $\begin{array}{c}23 \\
(7.7) \\
\end{array}$ & 115 & 122 \\
\hline Total & 1500 & $\begin{array}{c}1181 \\
(78.7) \\
\end{array}$ & $\begin{array}{c}228 \\
(15.2)\end{array}$ & $\begin{array}{c}91 \\
(6.1) \\
\end{array}$ & 574 & 607 \\
\hline
\end{tabular}

$\left({ }^{*} 23\right.$ oysters were lost during the culture period) 
Table 2. Summary of the harvested $P$. margaritifera cultured pearls in Rangiroa and Tahaa grow-out sites: number and percentage (in brackets) by donor family of cultured pearls, keshi and receiver oysters that had died due to natural mortality or predation after 16 months of culture.

\begin{tabular}{ccccccc}
\hline & Rangiroa & & & Tahaa & \\
\hline pearls & & Keshi & $\begin{array}{c}\text { Predation } \\
\text { and/or } \\
\text { mortality }\end{array}$ & $\begin{array}{c}\text { Harvested } \\
\text { pearls }\end{array}$ & Keshi & $\begin{array}{c}\text { Predation } \\
\text { and/or } \\
\text { mortality }\end{array}$ \\
\hline F058 & 89 & 5 & 17 & 83 & 14 & 20 \\
& $(80.2)$ & $(4.5)$ & $(15.3)$ & $(70.9)$ & $(12.0)$ & $(17.1)$ \\
F612 & 90 & 6 & 21 & 107 & 10 & 9 \\
F804 & $(76.9)$ & $(5.1)$ & $(18)$ & $(85)$ & $(7.9)$ & $(7.1)$ \\
& 99 & 0 & 15 & 107 & 4 & 8 \\
F805 & $(86.8)$ & $(0.0)$ & $(13.2)$ & $(89.9)$ & $(3.4)$ & $(6.7)$ \\
& 96 & 3 & 18 & 84 & 4 & 12 \\
F806 & $(82.0)$ & $(2.6)$ & $(15.4)$ & $(84.0)$ & $(4.0)$ & $(12.0)$ \\
& 94 & 1 & 20 & 107 & 3 & 12 \\
& $(81.7)$ & $(0.9)$ & $(17.4)$ & $(87.7)$ & $(2.5)$ & $(9.8)$ \\
\hline Total & 468 & 15 & 91 & 488 & 35 & 61 \\
& $(81.5)$ & $(2.6)$ & $(15.9)$ & $(83.6)$ & $(6.0)$ & $(10.4)$ \\
\hline & & & & & & \\
\hline
\end{tabular}

Table 3. Cultured pearl quality trait rates (\%) and corresponding numbers (in brackets), recorded for the two grow-out sites: Rangiroa and Tahaa. Surface defects were encoded as follows: 0 (no defect), 1 to 5 defects; 6 to 10 defects and >10 (up to 10 defects). Lustre on the cultured pearl surface was encoded as follows: "no" for absence and "yes" for presence of lustre. Cultured pearl classification grade was encoded as follows: A, B, C, D and R (for Rejects). Circles on cultured pearls were encoded as follows: "yes" for pearls with circles and "no" for the samples without. For shape categories, "B" corresponds to baroque or semibaroque shapes; "O" to oval, drop or button shape and "R" to round or semi-round shapes. Cultured pearl colour was classified in three ways: darkness level (low, moderate and dark). bodycolor or secondary colour, and visual colour categories, (grey, white, yellow, aubergine, green and peacock). The traits significantly different between the two grow-out locations at $p$ $<0.05,0.01<p<0.05$ and $p<0.001$ are indicated with 1,2 or 3 asterisk(s) ( $\left.{ }^{*}\right)$, respectively, and NS for not significant. 


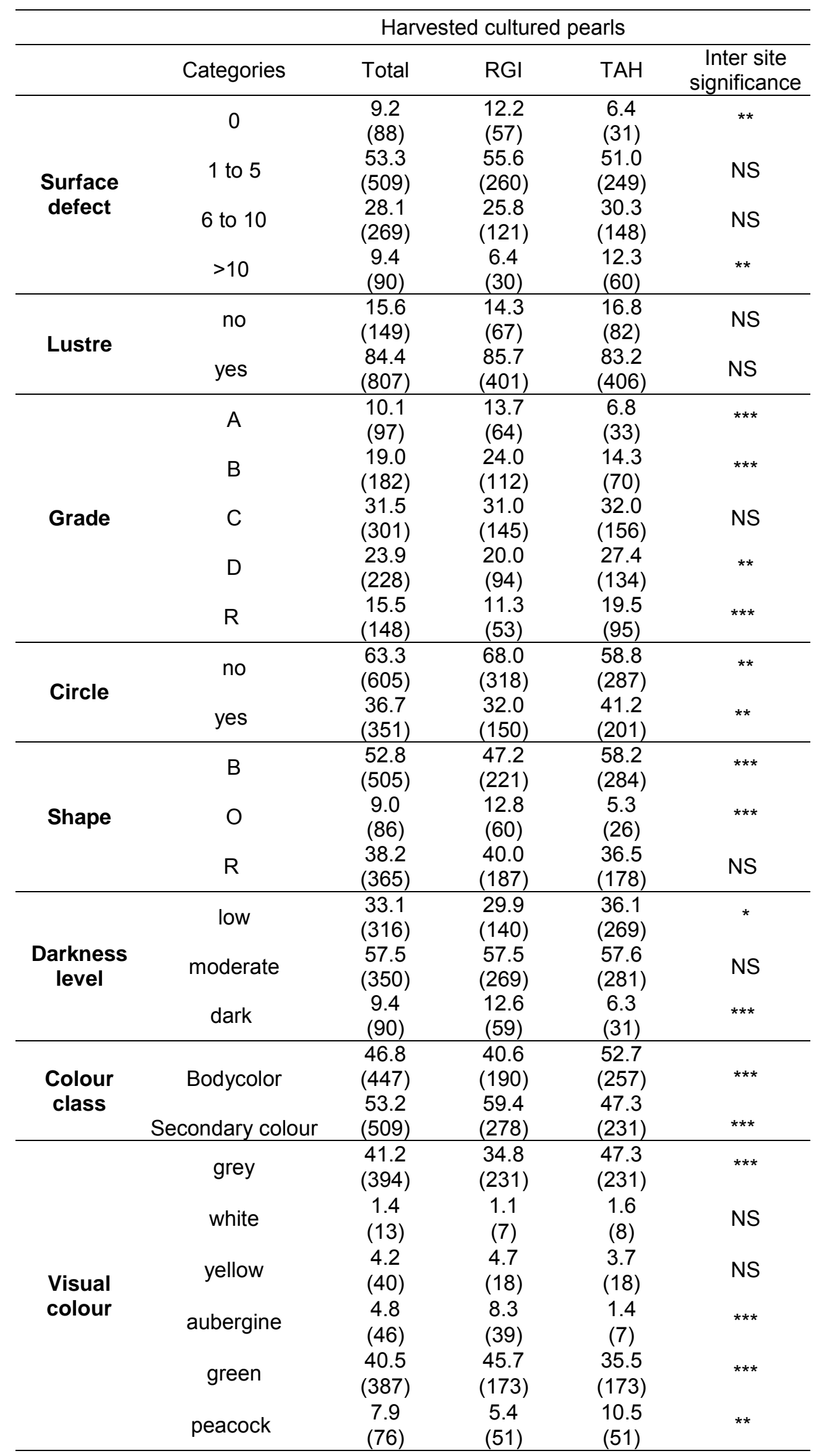




\section{Figures}

Fig. 1. Experimental design of $P$. margaritifera grafting, checking and culture operations. All the 1500 grafts operation was performed at Rangiroa. After checking, host oyster providing from each donor oyster were randomly split into two groups, one remain at Rangiroa and the second transferred to Tahaa. The harvests were realised in both sites.

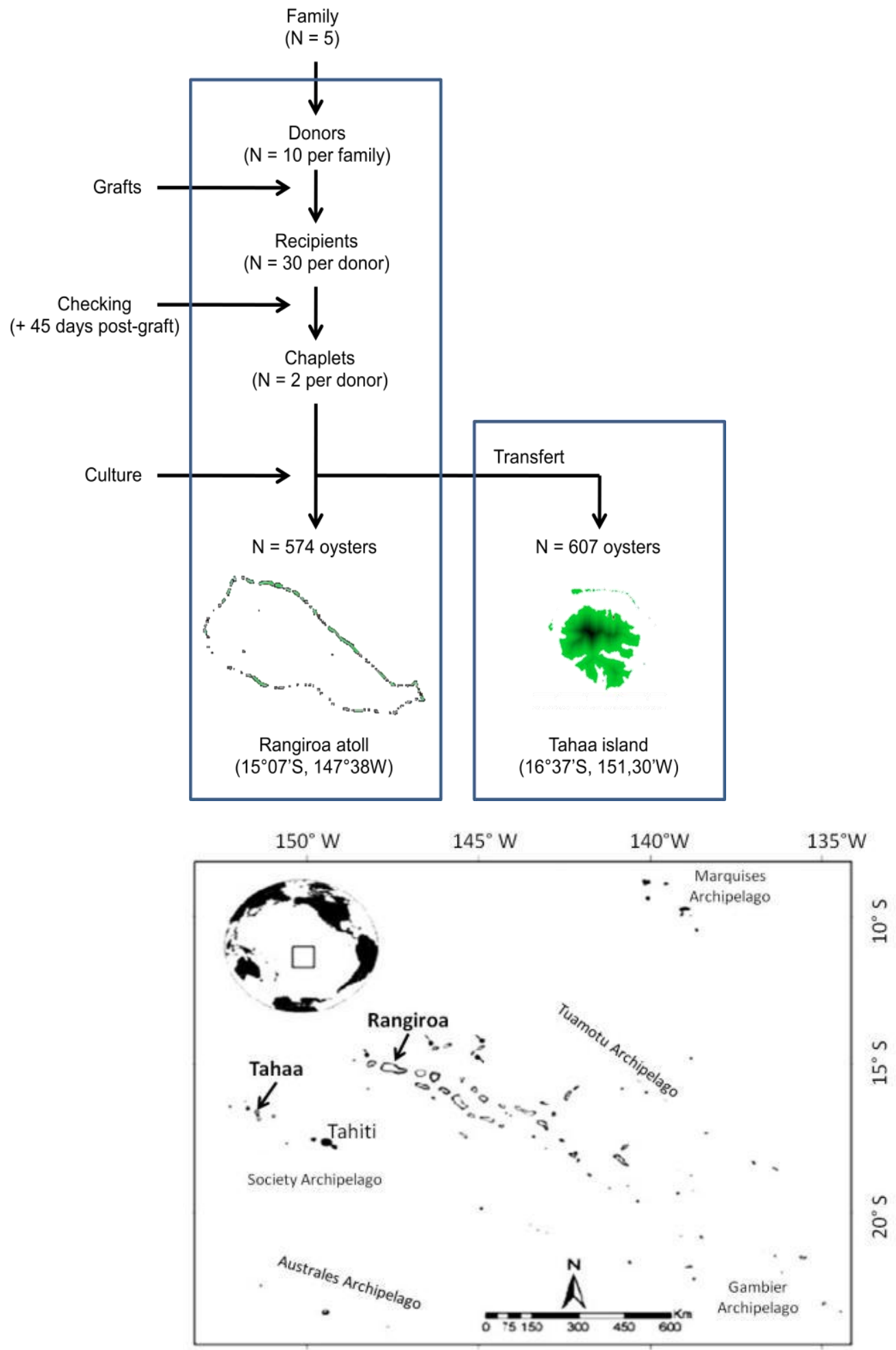


Fig. 2. Proportions (\%) of (a) each of the cultured pearl surface defect categories (four categories: no defect, 1 to 5 defects, 6 to 10 defects and more than 10 defects), (b) lustre (two categories: with or without lustre), (c) grade (five categories: $A, B, C, D$ and $R$ ), for each of the five $P$. margaritifera families reared at the Rangiroa (RGI) and Tahaa (TAH) grow-out sites. The data points significantly different $(p<0.05)$ for each family between the two grow-out sites are indicated with an asterisk $\left(^{*}\right)$ in the appropriate category on the TAH chart.

\section{a. Surface defect}

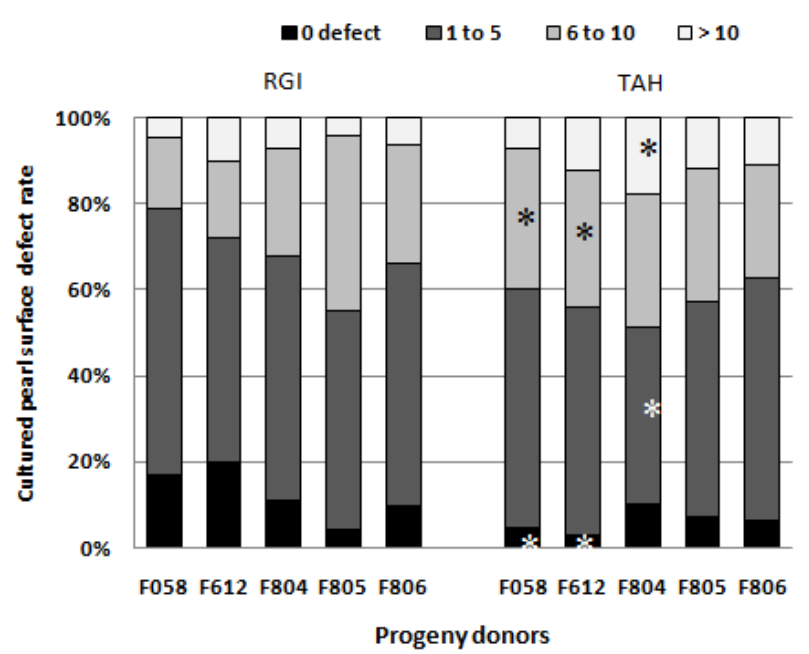

\section{b. Lustre}
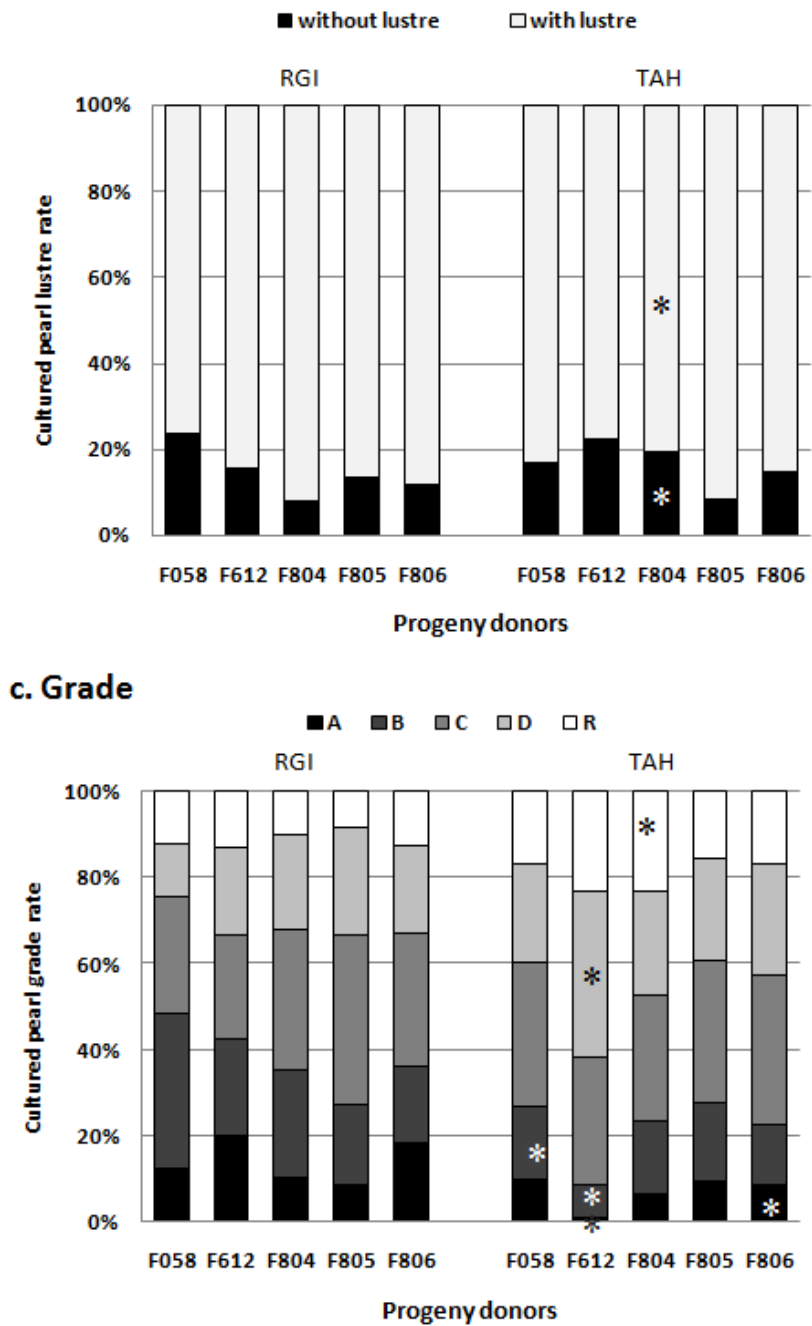
Fig. 3. Proportions (\%) of (a) cultured pearl darkness (three categories: low, moderate and high darkness), colour class (two categories: bodycolor and secondary colour), (c) visual colour (with its six categories: white, grey, yellow, peacock, green and aubergine), in each of the five $P$. margaritifera families reared at the Rangiroa (RGI) and Tahaa (TAH) grow-out sites. The data points significantly different $(p<0.05)$ for each family between the two grow-out sites are indicated with an asterisk $\left(^{*}\right)$ in the appropriate category on the TAH chart.

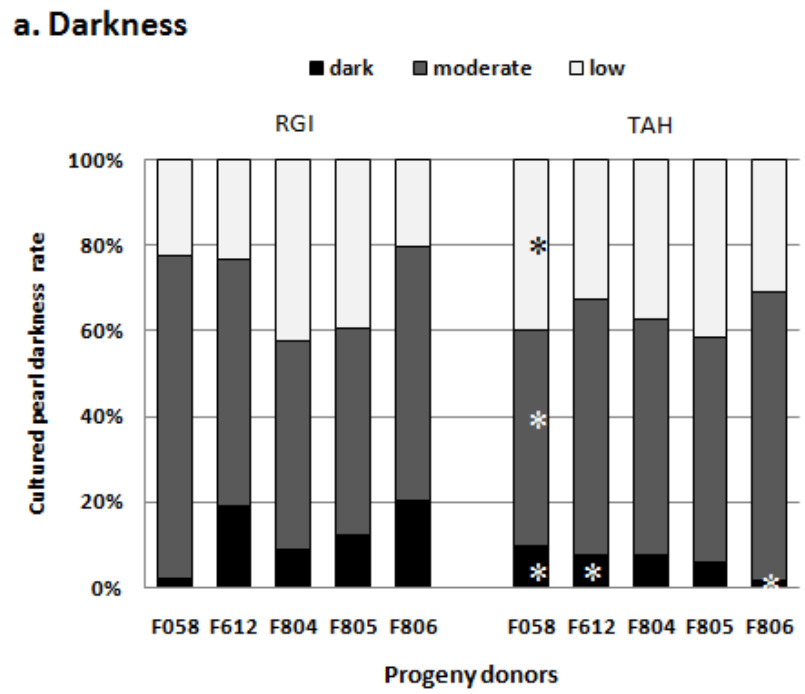

\section{b. Body and secondary colour}

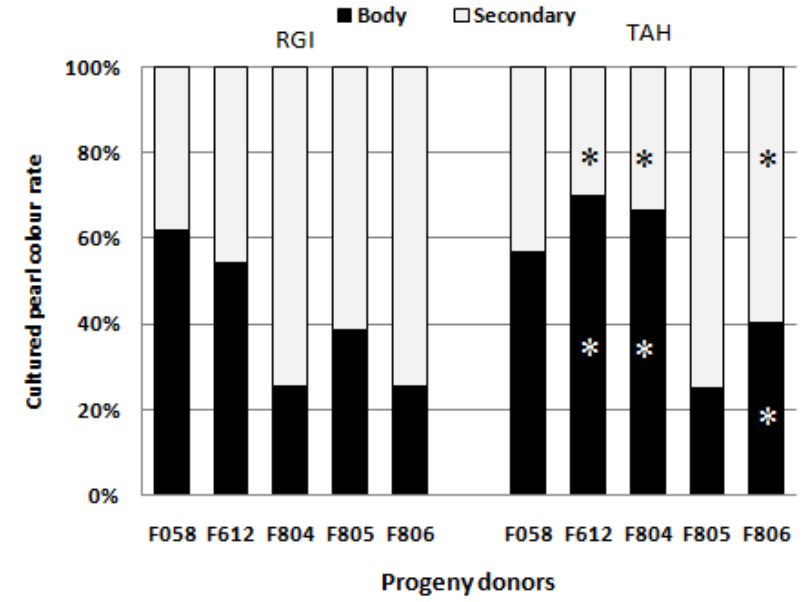

\section{c. Colour}

$\square$ white $\square$ grey $\square$ yellow $\square$ peacock $\square$ green $\square$ aubergine RGI TAH

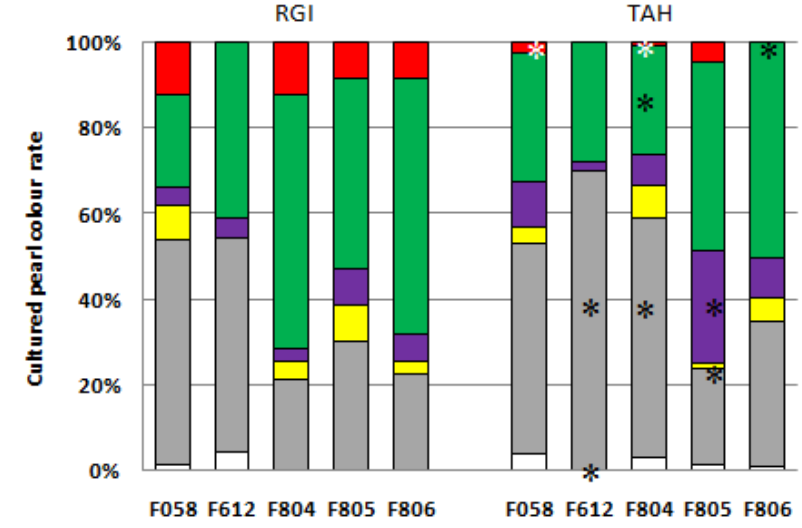

Progeny donors 